\title{
NORMALISASI STIGMA KEPOLISIAN NEGERI IMPIAN
}

\author{
Tri Siswanti \\ Fakultas IImu Sosial dan IImu Politik Universitas PGRI Palangka Raya \\ (email: trisa.wanto@gmail.com)
}

\begin{abstract}
Abstrak
Membangun citra dan reputasi positif di lembaga Kepolisian Republik Indonesia itu merupakan suatu keharusan dimana bagi Polri pada saat ini citra positif merupakan tujuan utama untuk memperoleh kepercayaan publik (public trust). Bersinggung dengan soal image dan reputasi Kepolisian Negeri Impian, sudah seharusnya lembaga ini harus serius menangani permasalahan tentang pencitraan, untuk mencapainya diperlukan usaha untuk memperbaiki citra Kepolisian Negeri Impian yang selama ini dianggap kurang profesional melalui Pengelolaan kesan dengan teknik normalisasi stigma.

Penulisan penelitian ini bertujuan:(1) mengkaji dan menganalisa Pengelolaan kesan dengan teknik normalisasi stigma,(2) mendeskripsikan Normalisasi stigma guna meningkatkan Citra di kepolisian Negeri Impian, dan (3) Mengelaborasi segala temuan dalam penelitian untuk merekomendasikan saran membangun opini baik yang dapat diterapkan dalam membangun Citra Kepolisian Negeri Impian. Peneliti menggunakan pendekatan kualitatif dengan metode fenomenologi. Teori yang digunakan adalah Pengelolaan kesan dengan teknik Normalisasi stigma dalam prespektif Erving Goffman. Adapun teknik pengumpulan data yang digunakan dalam penelitian ini adalah observasi, wawancara mendalam dan dokumentasi. Penentuan subyek adalah personel polisi yang melaksanakan program polisi promoter sebanyak 17 orang dan masa tugasnnya diatas tujuh tahun. Metode analisis data dilakukan dengan prosedur mentranskrip, bracketing, menginventarisir pertanyaan penting, cluster of meaning dan deskripsi esensi.

Temuan penelitian ini menghasilkan teknik pengelolaan kesan dengan teknik Normalisasi stigma bagi personel polisi yaitu: (a) dilakukan pemecatan pada anggota yang melakukan kesalahan yang berat, (b) pembinaan keagamaan terhadap personel Polri yang bermasalah dengan tingkat pelanggaran Ringan, (c) Memutasikan/memindah tugaskan personel Polri yang bermasalah dengan tingkat pelanggaran sedang, (d) Pimpinan harus bertindak tegas, (e) Pemimpin harus bisa menjadi suritauladan yang baik, (f) Memberikan penghargaan bagi personel yang berprestasi dan memberikan hukuman yang sesuai bagi personel yang bermasalah, (g) Memproses personel Polri yang bermasalah dengan berdasarkan asas keadilan dan Hak asasi manusia, (f) Melakukan revolusi mental dengan pembinaan keagamaan terhadap personel Polri yang bermasalah, (g) Bila pelanggaran ringan bisa diberikan hukuman fisik seperti lari 6 putaran, pushup 50 kali dan lain-lain, (h) Meningkatkan kesejahteraan personel Polri, (i) Memberi hukuman sesuai dengan tingkat
\end{abstract}


pelanggarannya, (j) Menurunkan pangkat setingkat lebih rendah, dan (k) Melakukan revolusi mental dimulai dari level pimpinan.

Kesimpulan hasil analisis penelitian adalah: Dalam normalisasi stigma harus dilakukan pemecatan dan penurunkan pangkat bagi personel polisi sesuai dengan tingkat pelanggarannya.

\section{Kata Kunci: Pengelolaan Kesan Dengan Teknik Normalitas Stigma}

\section{Pendahuluan}

Kepolisian adalah salah satu lembaga negara di Republik Indonesia yang yang memiliki slogan sebagai pengayom masyarakat. Selain itu aparat kepolisian juga memberikan pelayanan langsung kepada masyarakat seperti pelayanan pembuatan Surat Izin Mengemudi (SIM) dan menerima pengaduan masyarakat baik yang berupa tindakan kriminal, keamanan dan ketertiban masyarakat. Namun menurut salah satu masyarakat menyebutkan bahwa polisi kurang dekat dengan masyarakat, masih ada jarak tak terlihat yang membatasi antara polisi dengan Polisi. Selain itu, dalam menjalankan tugasnya, polisi masih bersifat pamrih dan tidak jarang meminta uang (Kompas.com, 2009)

Untuk itu, membangun citra dan reputasi positif di lembaga Kepolisian Republik Indonesia itu merupakan suatu keharusan dimana bagi Polri pada saat ini citra positif merupakan tujuan utama untuk memperoleh kepercayaan publik (public trust). Bersinggung dengan soal image dan reputasi Kepolisian Negeri Impian, sudah seharusnya lembaga ini harus serius menangani permasalahan tentang pencitraan, untuk mencapainya diperlukan usaha untuk memperbaiki citra Kepolisian Negeri Impian yang selama ini dianggap kurang profesional melalui Pengelolaan kesan. Pengertian citra itu sendiri abstrak (intangible) dan tidak dapat di ukur secara matematis, tetapi wujudnya dapat dirasakan dari hasil penilaian baik atau buruk (Ramdhani dan Wiwitan, 2018).

Keberadaan personel polisi sangat erat kaitannya dengan masyarakat, karena masyarakat yang memiliki pengaruh paling besar dan merupakan target utama dalam memberikan pelayanan kepada mereka. Kasus penyalahgunaan wewenang, penganiayaan, ketidakjelasan dalam penyampaian informasi suatu kasus, pelecehan seksual, perbuatan tidak menyenangkan, serta pengusutan kasus yang tidak kunjung selesai adalah gambaran penyelewengan yang dilakukan personel polisi di Negeri Impian. Sehingga perlahan-lahan akan membentuk opini negatif dan sikap ketidakpercayaan masyarakat terhadap lembaga Kepolisian (Trilaksono, 2015).

Kepolisian adalah pilar utama dalam menciptakan keamanan dan ketertiban masyarakat. Seharusnya opini yang terbentuk adalah polisi adalah sosok yang menjadi panutan untuk dijadikan contoh dan bisa diandalkan dalam memberikan perlindungan dan pelayanan kepada masyarakat. Bilamana terdapat penyalahgunaan wewenang dalam pelaksanaan tugas di lapangan hal ini akan membuat masyarakat ragu dengan kemampuan polisi dalam menjalankan tugas pokok dan fungsinya sebagai pelindung dan pelayan masyarakat.

Begitu kompleksnya tantangan tugas Polisi saat ini maka Lembaga ini harus 
betul-betul berbenah dalam segala hal seperti di bidang pembinaan, operasional maupun pembangunan. Sumber daya manusia serta sarana dan prasarana. Namun di sisi lain masih terdapat akses negatif dari peyelenggaraan tugas pokoknya berupa penyimpangan perilaku personil polisi seperti penyalahgunaan wewenang/ kekuasaan (abuse of power), dan melakukan perbuatan tercela lainnya yang melanggar kaidah-kaidah moral, sosial dan keagamaan (Ngatiya, 2012).

Berdasarkan hasil survey Transparency Internasional Indonesia Polri menduduki rangking kelima dari data lembaga/Institusi pemerintah yang paling banyak disorot masyarakat karena sering melakukan praktik KKN, dan akibatnya banyak sekali prestasi lembaga Kepolisian dalam bidang kamtibmas (pengamanan dan penertiban masyarakat) yang tertutupi oleh berbagai isu atau rumors yang berkaitan dengan penyelewengan aparat kepolisian. Sehingga citra di masyarakat sangatlah buruk, seolaholah tidak ada yang positif tentang citra polisi (rappler.com, 2017). Menurut Goffman (dalam Sengupta, Banks, Jonas, Miles, \& Smith, 2011; Genberg et al., 2007) mendefinisikan stigma adalah sebagai proses dinamis dari devaluasi yang secara signifikan mendiskredit seorang individu di mata individu lainnya. Stigmatisasi terhadap personel polri disebabkan karena polisi tidak bisa membatasi penampilan yang seharusnya dia simpan ini ditampilkan di depan panggung (front region) seperti apabila ada pelanggar lalu lintas dijalanan yang seharusnnya ditilang tapi malah diajak negosiasi untuk membayar langsung dan tidak diberi surat tilang.

Sesuai dengan Undang-Undang Nomor 2 tahun 2002 tentang Kepolisian Negara Republik Indonesia, Pasal 13 ayat (1) menyatakan: "Anggota Kepolisian Negara
Republik Indonesia dapat diberhentikan tidak dengan hormat dari dinas Kepolisian Republik Indonesia karena melanggar sumpah/janji anggota Kepolisian Republik Indonesia. Selanjutnya dalam pasal 1 Undang-Undang nomor 2 tahun 2002 berbunyi: Kepolisian adalah segala ihwal yang berkaitan dengan fungsi dan lembaga Polisi sesuai dengan peraturan perundangundangan.

Sesuai bunyi Undang-Undang diatas maka sudah seharusnnya Polisi mengayomi, melindungi dan melayani bukan sebaliknya melakukan penyalahgunaan wewenangnnya dan melakukan perbuatan tercela yang melanggar kaidah-kaidah moral, sosial dan keagamaan seperti: meminta upeti, mempersulit, dan menyakiti masyarakat. Selain itu sudah seharusnya personel polisi menjadi pelayan, pelindung dan pengayom masyarakat dengan tidak membedabedakan suku, agama ras atau golongan.

Memang tidak semua personel polisi menyebabkan citra yang buruk pada Kepolisian Negeri Impian hanya beberapa personel saja yang melakukan tindakan melanggar etika Kepolisian. Permasalahn ini diperlukan pembenahan di segala bidang yang dimulai dari petinggi-petinggi Polri sehingga penyebab jeleknya citra polisi dimasyarakat harus dihapuskan. Semboyan Promoter dalam rangkaian kebijakan dan agenda pembangunan Polri untuk lebih baik yaitu professional, modern dan terpercaya. Adanya komitmen untuk mewujudkan polisi promoter merupakan upaya untuk memperbaiki citra polisi yang selama ini dianggap kurang professional, kurang modern dan kurang dipercaya oleh masyarakat.

Pengelolaan kesan (Manajemen kesan) yang dikembangkan oleh Goffman merupakan bagian kajian teori dramaturgi. Pengelolaan kesan (pengelolaan kesan) 
adalah suatu usaha seorang individu yang dilakukan untuk dapat menciptakan kesan atau persepsi atas dirinya dihadapan publik. Pengelolaan kesan dilakukan terhadap simbol verbal ataupun simbol nonverbal yang melekat pada diri seseorang. Pada penelitian citra Polri mengkaji sejauhmana pengelolaan kesan berada di panggung depan (front region) maupun panggung belakang (back stage) pada diri seorang personel polisi di wilayah hukum Kepolisian Negeri Impian yang mana Goffman telah membagi menjadi dua arah berdasarkan aktor yang memainkan peran tersebut, yaitu:

a. Panggung depan (front region). Membahas tentang pengelolaan kesan yang perankan oleh aktor personel polisi berkaitan dengan aspek penampilan (appearance) serta gaya (manner).

1) Penampilan (appearance) dari pengelolaan kesan yang ditinjau berdasarkan segi penampilan yang dilakukan oleh aktor personel polisi meliputi sikap tampang dan pakaian. Bagaimana sikap tampang dan pakaian seorang personel polisi saat aktor tersebut ada bagian panggung depan (front region) yang diperlihatkan sehingga dapat menimbulkan kesan sebagaimana yang diinginkan oleh kalangan masyarakat Negeri Impian maupun oleh orang yang ada disekitarnya yang merupakan bagian dari pementasan di panggung depan.

2) gaya (manner) dari pengelolaan kesan merupakan bagian yang dilihat dari segi gaya yang dilakukan oleh aktor personel polisi yang berkaitan dengan perilaku, sikap, mimik wajah, bahasa tubuh, isi pesan, serta cara berbicara maupun gaya bahasa pada ssar sedang melaksanakan perannya sebagai polisi.

b. Panggung belakang (back stage). Peneliti meneliti kehidupan aktor polisi yang berada di jalan tempat pengaturan lalu lintas maupun di tempat kerja, apa saja yang dipersiapankan oleh aktor polisi yang ditinjau sebagaimana telah dipaparkan di depan, sehingga bisa terjun di kehidupan aktor front regionnya. Dengan demikian akan dapat diketahui terjadinya perbedaan yang signifikan pada proses pengelolaan kesan dari kehidupan aktor back stage-nya bila dibandingkan dengan kehidupan aktor front region. Ada beberapa segi penting yang merupakan bagian dari kehidupan back stage aktor polisi antara lain:

1) Penampilan. Meski penelitian ini meneliti tentang polisi Kepolisian Negeri Impian. Namun penampilan merupakan salah satu aspek yang menjadi fokus penelitian, karena pengelolaan kesan pada aktor polisi dapat memungkinkan ia menggunakan perias wajah pada kehidupan back stage-nya untuk kepentingannya;

2) Pakaian berfungsi untuk membuat pencitraan terhadap aktor yang memakainya. Sehingga aspek pakaian yang dikenakan oleh aktor polisi juga menjadi bahan kajian dari penelitian ini.

3) Sikap dan Perilaku Peneliti. Kajian ini fokus pada sikap dan perilaku dari aktor polisi di Kepolisian Negeri Impian.

4) Bahasa Tubuh merupakan salah satu identitas atau ciri khas dari aktor. Sebagaimana aktor polisi Kepolisian Negeri Impian, yang bisa dilihat pengelolaan kesan melalui gerak bahasa tubuhnya. 
5) Mimik Wajah merupakan bentuk ekspresi dari aktor saat mereka melakukan interaksi.

Sosiolog Erving Goffman (dalam Sengupta, Banks, Jonas, Miles, \& Smith, 2011; Genberg et al., 2007) mendefinisikan stigma sebagai proses dinamis dari devaluasi yang secara signifikan mendiskredit seorang individu di mata individu lainnya. Stigma dapat juga didefinisikan sebagai suatu fenomena yang dapat memengaruhi diri individu secara keseluruhan (Crocker dkk., Jones dkk., Link \& Phelan dalam Major\&O'Brien, 2005). Menurut Goffman (dalam Scheid \& Brown, 2010) menyatakan bahwa "stigma concept identifies an attribute or a mark residing in the person as something the person possesses" artinya bahwa konsep stigma mengidentifikasi atribut atau tanda yang berada pada seseorang sebagai sesuatu yang dimiliki. Stigma juga berarti sebuah fenomena yang terjadi ketika seseorang diberikan labeling, stereotip, separation, dan mengalami diskriminasi (Link Phelan dalam Scheid \& Brown, 2010). Goffman (1963) mengatakan bahwa, melalui passing, covering serta techniques of information control maka seseorang dapat mengurangi dampak dari stigma bahkan bisa menghindari stigma. Teknik-teknik digunakan secara berkesinambungan satu sama lainnya pada proses terjadinya stigmatisasi.Passing dilakukan dengan cara melakukan perpindahan dari satu kelompok ke kelompok lain, misalnya dari kelompok yang memiliki stigma ke kelompok yang memiliki stigma kurang negatif dari kelompok sebelumnya atau bahkan kekelompok yang tidak memiliki stigma. Pelaku passing biasanya menganggap dirinya (yang memiliki stigma) bukan bagian dari orang yang di stigma Passing merupakan usaha untuk menyamarkan/menyembunyikan stigma dari sekelompok orang yang tidak mengetahui tentang stigma tersebut atau terhadap orang-orang yang diharapkan tidak mengetahui stigma yang dimiliki. Passing hanya bisa dilakukan saat pihak lain tidak mengetahui atau hanya pihak tertentu saja yang mengetahui tentang stigma atau atribut yang dimiliki seseorang yang mungkin menjadi stigma di masyarakat. Pada kondisi ini, mereka pelaku passing berupaya untuk memposisikan dirinya pada tempattempat dimana ia bisa menyembunyikan jati dirinya. Tahapan berikutnya saat seseorang melakukan passing yaitu melakukan kontrol atas informasi berkaitan dengan dirinya terhadap lingkungan sosialnya. Mengkontrol informasi dilakukan oleh orang yang distigma guna menghindar dengan berbagai cara, supaya orang tidak sadar dengan kekurangan yang dimilikinya serta dianggap sebagai bagian dari kelompok orang normal, atau paling tidaknya membuat atribut yang ada pada dirinya menjadi kurang terstigma. Dilakukan dengan membatasi pengetahuan orang lain berkaitan dengan kekurangan yang ada pada dirinya. Adapun covering merupakan tahapan akhir terhadap mereka yang memiliki stigma yang telah diketahui oleh publik serta mau menerima stigma tersebut sebagai bagian dirinya. Covering bertujuan untuk meminimalisir supaya stigma tidak tampak dengan jelas sehingga tidak mengganggu terjadinya interaksi sosial antara pemilik stigma dengan kelompok normal lainnya.

\section{Jurnal Sociopolitico}




\section{Metode Penelitian}

Paradigma penelitian ini menggunakan paradigm definisi sosial digunakan untuk memahami tindakan sosial individu yakni tindakan individu yang penuh arti. Dengan paradigma definisi sosial dapat dikaji proses pengelolan kesan dengan teknik normalisasi stigma dalam meningkatkan citra di Kepolisian Negeri Impian. Berdasarkan paradigma definisi sosial, maka penelitian ini menggunakan pendekatan kualitatif. Alasan penggunaan pendekatan kualitatif sebagaimana pendapat McCusker, K., \& Gunaydin, S.(2015), bahwa pemilihan penggunaan metode kualitatif dalam hal tujuan penelitiannya adalah untuk memahami bagaimana suatu komunitas atau individuindividu dalam menerima isu tertentu. Dalam hal ini, sangat penting bagi peneliti yang menggunakan metode kualitatif untuk memastikan kualitas dari proses penelitian, sebab peneliti tersebut akan menginterpretasi data yang telah dikumpulkannya. Jenis penelitian ini adalah penelitian fenomenologi. Alfred Schutz (1941) dalam Philosophy and Phenomenological Research menjelaskan bahwa fenomenologi merupakan upaya untuk memahami arti setiap perilaku, ucapan serta interkasi dalam suatu peristiwa maupun yang dikaitkan dengan situasi tertentu sebagai suatu syarat adanya eksistensi sosial. Lokasi penelitian peneltian ditentukan secara sengaja (purposive) di Kepolisian Negeri Impian. peneliti menggunakan teknik purposive dalam rangka mendapatkan data dan informasi yang valid. Pengumpulan data dalam penelitian ini menggunakan beberapa teknik yaitu observasi, wawancara dan dokumentasi. Ketiga teknik ini dilakukan secara simultan sesuai dengan kebutuhan data penelitian guna mendapatkan data yang valid dan reliabel. Peneliti menggunakan teknik Analisis Data model interaktif dan komparatif dari Miles dan Huberman (1992). Teknik ini dilakukan dengan cara membandingkan antara hasil penelitian dengan hasil penelitian sebelumnya dan menggunakan uji validitas atau keabsahan data menurut Creswell (2010).

\section{Hasil dan Pembahasan}

Hasil temuan penelitian tentang
pengelolaan kesan dengan teknik
Normalisasi stigma temuannya adalah: (a)
dilakukan pemecatan pada anggota yang
melakukan kesalahan yang berat, (b)
Menurunkan pangkat setingkat lebih
rendah,
(c) memindahtugaskan personel Polri yang bermasalah dengan tingkat pelanggaran sedang, (d) Pimpinan harus bertindak tegas, (e) Pemimpin harus bisa menjadi suri tauladan yang baik, (f) Memberikan penghargaan bagi personel yang berprestasi dan memberikan hukuman yang sesuai bagi personel yang bermasalah, (g) Memproses personel Polri yang bermasalah dengan berdasarkan asas keadilan dan Hak asasi manusia, (f) Melakukan revolusi mental dengan pembinaan keagamaan terhadap personel Polri yang bermasalah, (g) Bila pelanggaran ringan bisa diberikan hukuman fisik seperti lari enam putaran, pushup limapuluh kali dan lain-lain, (h) Meningkatkan kesejahteraan personel Polri, (i) Memberi hukuman sesuai dengan tingkat pelanggarannya, (j) pembinaan keagamaan terhadap personel Polri yang bermasalah dengan tingkat pelanggaran ringan, dan (k) Melakukan revolusi mental dimulai dari level pimpinan.

\section{Jurnal Sociopolitico}




\section{Kesimpulan}

Peneliti ini mengkaji dan menganalisa tentang pengelolaan kesan dengan teknik normalisasi stigma menggunakan dramaturgi sebagai dampak dari stigma menggunakan program polisi promoter. Dengan menggunakan rancangan penelitian kualitatif dan pendekatan fenomenologi. Penelitian fenomenologi menjelaskan dan mengungkapkan pengelolaan kesan dan pengalaman yang didasari oleh kesadaran yang terjadi. Dikaitkan dengan teori dramaturgi dan teknik mengurangi/ menghilangkan stigma menurut Erving Goffman.

Dari temuan penelitian tersebeut di atas dapat disimpulkan bahwa: "Dalam normalisasi stigma harus dilakukan pemecatan dan penurunkan pangkat bagi personel polisi sesuai dengan tingkat pelanggarannya".

\section{Saran}

Berdasarkan penelitian tentang pengelolaan kesan dengan teknik Normalisasi stigma dapat direkomendasikan adalah:

1. Bagi Lembaga Polri

a. Dalam pengelolan kesan diperlukan komitmen moral yang kuat dari pimpinan karena komitment pimpinan memberi sumbangsih yang besar dalam merubah mental anggota personel polisi karena polisi menganut sistem hierarki sehingga siapapun pemimpinnya bawahan harus loyal dan patuh. Bawahan harus tunduk dan bawahan harus tunduk dan takut.

b. Personel polisi tunduk kepada hierarki yang berlaku dan tentunya memiliki landasan kerja, kode etik profesi dan disiplin yang sesuai dengan peraturan yang berlaku di Institusi Polisi.

c. Melakukan pembinaan revolusi mental secara berkesinambungan dan terus-menerus sehingga tertanam sikap, etika yang baik dan bisa diterapkan dalam kehidupan seharihari.

d. Melakukan evaluasi dan monitoring secara berkala dan terus-menerus untuk meningkatkan profesionalisme personel polisi dan memperbaiki mutu pelayanan dengan menggunakan Ilmu pengetahuan Teknologi dan media sebagai sarana penunjang keberhasilan pelaksanaan tugas.

2. Bagi personel polisi

Diharapkan dengan pengelolaan kesan dan teknik mengurangi stigma, personel polisi dapat mempunyai komitment kuat untuk menjaga kualitas pelayanan publik dan personel polisi bisa bekerja secara professional sebagai aparat penegak hukum dan penjaga ketertiban masyarakat yang tidak bisa dilakukan dengan sikap mental yang buruk, sehingga setiap personel polisi akan menyadari bahwa citra lembagannya harus dijaga dengan penuh kehati-hatian.

3. Bagi masyarakat

Masyarakat perlu perduli dan memahami Polisi lahir karena adannya masyarakat, dan masyarakat membutuhkan kehadiran polisi dalam menjaga ketertiban, keamanan dan keteraturan masyarakat itu sendiri. Dalam menjaga Kamtibmas Polisi akan berhasil bila terdapat partisipasi masyarakat. Oleh karenannya masyarakat juga harus mampu menempatkan dirinya menjadi polisi bagi dirinnya sendiri, sehingga diperlukan unsur penekanan dengan 
kehadiran petugas kepolisian di tengah masyarakat dalam setiap waktu dan tempat guna meningkatkan disiplin dan kepatuhan masyarakat.

\section{Referensi}

Arief, Barda Nawawi. (1998). Beberapa Aspek Kebijaksanaan Pengakuan dan Pengembangan Hukum Pidana. Bandung: Citra Aditya Bakti.

Arief, Effect. (2018). Setahun Reformasi Senyap di Dapur Polri. Jakarta: Diandra Kreatif.

Arifin, Anwar. (2014). Politik Pencitraan. Yogyakarta: Graha Ilmu.

Bungin, Burhan. (2001). Metodelogi Penelitian Kualitatif. Jakarta: PT Raja Grapindo Persada.

Gerungan, W. A. (1996). Psikoligi Sosial. Bandung: Eresco.

Goffman, Erving. (1959). The Presentation of Self in Everyday Life. United States of America: Doubleday Anchor Books.

Haryamawan, RMA. (1986). Dramaturgi. Bandung: PT Remaja Rosdakarya.

Krippendorf, Klaus. (1993). Analisis Isi: Pengantar Teori Dan Metodologi. Jakarta: PT. Raja Grafindo Presada.

Kunarto. 2001. Perilaku Organisasi POLRI. Jakarta: Cipta Manunggal.

Kuswarno, Engkus. (2007). Manajemen Komunikasi Pengemis, Dalam Metode Penelitian Komunikasi: Contoh-contoh Penelitian Kualitatif dengan Pendekatan Praktis. Bandung:

RemajaRosdakarya

(2009). Metodelogi

Penelitian

Komunikasi

Fenomenologi, Bandung: Widya Pajajaran.
Lubis, Mochtar. (1998). Citra Polisi. Jakarta: Yayasan Obor Indonesia.

Moleong, Lexy J. (2007). Metodologi Penelitian Kualitatif, Edisi Revisi, Bandung. PT. Remaja Rosdakarya.

. (1989). Metodologi

Penelitian Kualitatif. Bandung: Remadja Rosdakarya.

Mulyana, Deddy. (2001). Ilmu Komunikasi Suatu Pengantar. Bandung: PT. Remaja Rosdakarya . (2008). Metode Penelitian

Komunikasi: $\quad$ Contoh-Contoh

Penelitian Kualitatif dengan Pendekatan Praktis. Bandung: Remaja Rosdakarya.

Mulyana, Deddy. (2006). Pengantar Sosiologi Komunikasi. Jakarta: Prenada Media Group.

Raharjo, Satjipto dan Tabah, Anton. (1993). Polisi Pelaku dan Pemikir. Jakarta: PT Gramedia Utama.

Raharjo, Satjipto. (2002). Polisi Sipil dalam Perubahan Sosial di Indonesia. Jakarta: Kompas.

Raho, Bernard. (2004). Sosiologi: Sebuah Pengantar. Surabaya: Sylvia.

Rakhmat, Jalaluddin. (2008). Psikologi Komunikasi. Bandung: PT. Remaja Rosdakarya.

Riduwan. (2004). Metode Riset. Jakarta: Rineka Cipta.

Ruslan, Rosady. (1994). Praktek Dan Solusi Public Relations Dalam Situasi Krisis Dan Pemulihan Citra. PT. Ghalia Indonesia, Jakarta.

Schlenker, B. R. (1980). Impression management: The self-concept, social identity and interpersonal relation. Monterey, CA: Brooks/Cole

Soehartono, Irawan. (1995). Metode Penelitian Sosial. Bandung: PT Remaja Rosdakarya

\section{Jurnal Sociopolitico}


Soekanto, Soejono. (1990). Sosiologi Suatu Pengantar. Jakarta: PT. Raja Grafindo Persada.

Sugiyono. (2006). Memahami Penelitian Kualitatif. Bandung: Alfabeta.

Tabah, Anton. (1991). Menatap dengan Mata Hati Polisi Indonesia. Jakarta: PT Gramedia Pustaka utama.

Widodo, Suko. 2010. Anatomi dan Perkembangan Teori Sosial. Aditya Media Publishing. Malang.

\section{Jurnal dan Tulisan Ilmiah:}

Alim, Chelse Amand (2014). Normalisasi stigmaAgnes Monica Melalui AkunInstagram (@agnezmo) Jurnal e---Komunikasi 1-10.

Ariani, D. Wahyu. (2014). Pengaruh Manajemen Impresi Pada Perilaku Kewargaan Organisasional: Suatu Studi Empiris. Jurnal Bisbis Teori dan Implementasi. Vol. V, No. 1, Februari 2014. Hal. 11-41.

Bahri, Andini Nur. (2018). Peran Komunikasi Antar Pribadi Pada Lingkungan Kerja Dalam Perspektif Islam. Jurnal Ilmiah Sosiologi Agama Prodi Sosiologi Agama Fakultas Ilmu Sosial UIN SU Medan. Vol.1, No.1 , Juni Tahun 2018. Hal. 128-142.

Bolino, M. C., Kacmar, M. K., Turnley, W. H., \& Gilstrap, B. J. (2008). A Multilevel Review Of Normalisasi stigmaMotives And Behaviors. Journal of Management.

Davies, J. (2007). Display, Identity, And The Everyday: Self-Presentation Through Online Image Sharing. Journal of Cultural Politics Education, 28(4), 549-564

Dewisyahyada Tami Mutiya dan Fahmi, M. Husen. (2018). Dramaturgi Kehidupan Hakim di Pengadilan
Negeri Bandung (Dramaturgy Of The Judge's Life In The Court Of Bandung). Prosiding Hubungan Masyarakat. ISSN: 2460-6510. Volume 4, No. 2, Tahun 2018 Hal. 469-476.

Godfrey, D., Jones, E. E., \& Lord, C. G. (1986). Self-promotion is not ingratiating. Journal of Personality and Social Psychology, 50, 106115

Harbet, Parlin. (2018). Pengelolaan Normalisasi stigmaDan Implementasi Perilaku Feminim Make-Up Artist Pria. Jurnal Media Kom, Vol.VIII, No.2, Desember 2018. Hal. 58-63

McCusker, K., \& Gunaydin, S. (2015). Research using qualitative, quantitative or mixed methods and choice based on the research. Perfusion. DOI: 10.1177/0267659114559116

Ngatiya. (2012). Penegakan Hukum Kode Etik Profesi Polrsi terhadap Anggota Polri Yang Melakukan Tindak Pidana (Studi Kasus Pada Polresta Pontianak). Thesis. Medan: Universitas Sumatera Utara.

Pramudita Rah Mukti. (2014). Strategi Pengemis Dalam Hidup Bermasyarakat di Kota Surabaya, jurnal On-line Komunitas Sosiologi FISIP Universitas Airlangga Vol. 1 No. 1, Januari 2013. http://journal.unair.ac.id (diakses di Bandung tanggal 10 april 2014).

Pudjiastuti, Wahyuni dan Fadhal, Soraya. (2012). Opini Mahasiswa Terhadap Citra Polisi Republik Indonesia (POLRI). Jurnal AlAzhar Indonesia Seri Pranata

\section{Jurnal Sociopolitico}


Sosial, Vol. 1, No. 3, Maret 2012. Hal. 201-216

Pujileksono, Sugeng. (2010). Runtuhnya Penjara Sebagai Institusi Total. Artikel. Volume 13 Nomor 1 Januari - Juni 2010. Hal. 81-94.

Purnamasari, R. Ira Isprafika. (2007). Peran humas polri dalam meningkatkan citra kepolisian. Skripsi. Fakultas Ilmu Komunikasi Universitas Mercu Buana Jakarta.

Putra, Gisky Andria. (2017) Pengelolaan Kesan Oleh Pengemis (Studi Deskriptif Dramaturgi Terhadap Pengemis Di Sekitar Jalan Permindo Kota Padang) Majalah Ilmiah. Vol. 25 Issue 2 173-180.

Ramdhani, Dikdik dan Wiwitan, Tresna. (2018). Citra Ridwan Kamil Dikalangan Wartawan (Studi Kasus Citra Ridwan Kamil di Media Sosial sebagai Walikota Bandung dikalangan Wartawan). Prosiding Hubungan Masyarakat. Volume 4, No. 2, Tahun 2018. Hal. 761-767

Rosenfeld, P., Giacalone, R. A., \& Tedeschi, J. T. (1983). Humor and impression management. Journal of Social Psychology, 130(4), 495500.

Sofiawati, Miranti. (2017) "Studi Dramaturgi Mengenai Motivasi dan Perilaku Pengamen Dalam Menjalankan Kehidupan Dikota Bandung”. Universitas Pasundan Bandung.

Suneki, Sri dan Haryono. (2012). Paradigma Teori Dramaturgi Terhadap Kehidupan Sosial. Jurnal Ilmiah CIVIS, Volume II, No 2, Juli 2012. Hal. 1-13.

Viswesvaran, Chockalingan; Ones, Denize S.; dan Hough, Leaetta M. (2001). Do Normalisasi stigmascale in
Personality Inventories Predict Managerial Job Performance ratings?. International. Journal of Selection and assessment, 9(4): 277-289

Wawin, Dionisius C. Uran. (2014). Drama Kehidupan Ladies Yang Bekerja Di Mitra Pub Cafe \& KTV Samarinda. eJournal Sosiologi Konsentrasi, Volume 2 , Nomor 1 , 2014. Hal. 1-19

\section{Artikel Online:}

http://forikes-ejournal.com/index.php/SF

Jurnal -Penelitian Kesehatan Suara Forikes

FER. (2016). Kapolri Sebut Polwan Ujung

Tombak Program Promoter. https://www.beritasatu.com/nasion al/382282/kapolri-sebut-polwanujung-tombak-program-promoter. Diakses 11 Oktober 2018.

Kompas.com . (2009). "Polisi Tetap Buruk di Mata Masyarakat", https://megapolitan.kompas.com/r ead/2009/07/01/22265746/polisi. tetap. buruk.di.mata.masyarakat Diakses pada 13 Desember 2018.

Maskun. (2013). Profesionalisme Polri. Diunduh dari:

http://www.negarahukum. com/hukum/profesionalismepolri.html. 20 Desember 2018.

Sumandoyo, Arbi. (2017). "Buruk Polri di Mata Masyarakat", https://tirto.id/cmwM Diakses pada 16 Oktober 2018.

Tempo.co. (2016). Gambaran Ideal Polisi di Masa Mendatang. Kamis, 15 September 2016 16:42 WIB. https://nasional.tempo.co/read/804 483/ gambaran-ideal-polisi-dimasa-mendatang. Diakses pada 15 Oktober 2018.

Trilaksono, Medi D.A. (2015). Peran Bidang Humas Kepolisian Daerah 
Istimewa Yogyakarta Dalam Manajemen Komunikasi Publik. Universitas Gadjah Mada. Diunduh dari http://etd.repository.ugm.ac.id/ 17 Oktober 2018.

(http://www.kompasiana.com/mariaharday anto/jangan-beri-uangpadapengemis_550e11b8a33311b 02dba7f42). Diakses pada 28 juli 2016

http://www.iiste.org ISSN 2422-8451 An International Peer-reviewed Journal Vol.37, 2017jurnal of Marketing and Consumer Research.

https://nasional.kompas.com/read/2016/08/ 18/18524141/faktor.yang.membuat .kepercayaan.publik.rendah.terhad ap.polisi.versi.jenderal.tito

https://www.kompasiana.com/adrian.su4/5 518346aa333118007b66398/maafpak-polisi-kami-belum-bisapercaya-kalian

https://ferli1982.wordpress.com/2018/08/0 2/mengapa-harus-promoter/ https://www.kompasiana.com/agus_oloan/5 95ddf7643322f12843fcf02/mewuju dkan-revolusi-mental-indonesiadari-polisi-promoter

https://www.rappler.com/indonesia/berita/1 63647-hasil-survei-transparencyinternational-indonesia-dprlembaga-terkorup https://news.detik.com/berita/d4227042/survei-lsi-polisipengadilan-dan-pns-instansipaling-ko

\section{Jurnal Sociopolitico}

